\title{
ANALYTICAL NETWORK PROCESS BASED ON BOCR ANALYSIS AS AN APPROACH FOR DESIGNING A FOREIGN DIRECT INVESTMENT POLICY
}

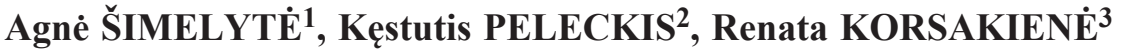 \\ Department of Economics and Management of Enterprises, Vilnius Gediminas \\ Technical University, Sauletekio al. 11, LT-10223, Vilnius, Lithuania \\ E-mail: 1agne.simelyte@vgtu.lt (correspondingauthor); \\ ${ }^{2}$ kestutis.peleckis@vgtu.lt; ${ }^{3}$ renata.korsakiene@vgtu.lt \\ Received 24 September 2014; accepted 12 October 2014
}

\begin{abstract}
Foreign direct investment is significantly important for the emerging market countries or countries in transition. Scientific literature provides plenty of evidence that FDI may have both negative and positive influence on economic growth. However, research proves that just specific type of FDI may bring benefit to the host country. Thus, a targeted FDI policy is essential for directing foreign capital into problematic business areas or regions. The goal of the article is to propose a complex targeted FDI policy, the employment of which would give benefits to the host country and achieve its strategic goals. Benefit-opportunities-costs-risks analysis and analytic network process method are used for the empirical research. Final results reveal that Lithuania, attracting FDI into research and development area, gains great benefits and exploits opportunities. At the same time, the highest costs might be generated while implementing a FDI policy in this area. A FDI policy towards service sectors would cause the least amount of risks. These results are significant for academics as the basis for further research, and decisions-makers as guidance for the development of the national FDI policy.
\end{abstract}

Keywords: FDI, FDI policy, multinational corporations, MCDM, decision-making tool, BOCR, ANP, Lithuania.

JEL Classification: C61, F12, H59, M48.

\section{Introduction}

Interest in attracting foreign direct investment (FDI) has increased since the 1980s, as it is one of the external financing sources for developing and developed countries. However, scientists (Long et al. 2015; Aurangzeb, Stengos 2014; Cooray et al. 2014; Du et al. 2014; Fenny et al. 2014; Medvedev 2010) still argue whether the impact of foreign capital on economic growth is positive or negative. Some researchers state that inward FDI is limited to a short-term positive impact, or positive effect of FDI is possible only in long-term (Belloumi 2014; Merlevede et al. 2014), while others (Long et al. 2015; Zhang 2014) maintain that the performance of multinational corporations (MNCs) cannot be harmful for the host country at all, and FDI has only positive influence on 
economic growth. Gui-Diby (2014) claims that the impact of FDI on economic growth may be twofold. In order to achieve positive effect of FDI, he recommends designing a FDI policy and implementing some measures. The representatives of Dependencia School disagree with Gui-Diby (2014) and maintain that host country by attracting FDI becomes dependent on MNCs. Meanwhile, Aurangzeb and Stengos (2014) conclude that countries with higher levels of FDI inflows experience higher productivity in the export sector compared to those with low level of FDI inflows. Zhang's (2014) study confirms that higher FDI flows positively affect industrial performance and positive impact increases in time. For example, Markusen (2013) especially emphasizes the host country's need for external funding that might be used to upgrade technologies and promote innovation. In this sense, the host country should attract specific MNCs motivated towards expanding business through research and development. This means that the host country should focus on the measures, which would attract targeted investors. Moreover, a strategy or a policy would help define goals for selecting proper FDI incentives and creating a framework for implementing them. The FDI policy assumed by the host country and applicable measures enables international companies to integrate into the host market as well as to expand production by using local labour force, land and capital. Meanwhile, the practice shows that the host governments forming their FDI policy expect positive impact on economic growth from FDI, and do not evaluate the costs and risks, which may occur after employing specific incentives. Thus, the employed incentives may be treated as investments in FDI, or in other words, investments in attracting MNCs. For this reason, these incentives may not pay off, but result in a loss. In some cases host governments tend to attract foreign capital as much as possible. For example, Belloumi (2014), analysing the measures for attracting FDI in Tunisia, finds that there is no significant Granger causality from FDI to economic growth in the short run. Even more, he admits that empirical results failed in proving positive spillovers from FDI. Meanwhile, Bjorvan and Eckel (2006) have some doubts that the policy influences FDI flows. These scientists define two types of FDI policies: bottom-up and top-down. The latter is applied using the existing business environment and directing FDI to particular regions or business sectors. In order to attract MNCs into R\&D, a bottom-up policy is employed. Other scientists (Du et al. 2014), examining whether an industrial policy affects the magnitude and directions of FDI spillovers, discover that tariff reform increased the productivity impacts of FDI's backward spillovers in China. Thus, the conclusion might be drawn that the changing direction of a FDI policy affects inward foreign capital flows. The investigation of Long et al. (2015) proves that even domestic companies may benefit from adopted FDI incentives. They discover that Chinese domestic firms located in regions with a higher level of FDI tend to enjoy a lower level of tax and fee burdens, less arbitrariness in such burdens, as well as better legal protection. Cooray et al. (2014) notice that developing countries tend more intensively compete for FDI between each other than highly developed countries. However, the drastic application of one or other policy type may cause a "race to the bottom". Due to this phenomenon, government regulation declines, the costs of attracting FDI increases and the local market faces a high level of competition. In order to form a targeted FDI policy, it is required to choose a proper method and methodology. However, it is 
noticeable that factors, influencing the formation of FDI, are being evaluated perfunctorily. The problem arises during the selection of methods for a FDI policy formation. Frequently, methods, based on correlation-regression analysis, are applied in the scientific literature. However, this analysis is more helpful in assessing relationship between individual factors than complex components of the FDI policy.

The goal of the article is to form a complex targeted FDI policy, the employment of which would bring benefits to the host country and allow achieving its strategic goals. The following methods are applied in the research: benefit-opportunities-costs-risks (BOCR) analysis and analytic network process (ANP) method.

\section{Literature review}

\subsection{Models for designing a FDI policy}

Popular econometric and multi-criteria methods are widely adopted for analysis of a FDI policy and the impact of foreign capital on economic growth. However, a significant number of researchers limit their investigations by exploring the FDI impact without considering the FDI policy or measures for attracting MNCs. In this way, the question regarding the effectiveness of the FDI policy remains unanswered. It is not clear whether negative or positive influence of FDI on economic growth is caused by the FDI policy and incentives or not. Filippov and Costa (2007) define two approaches to the FDI policy: quantitative and qualitative approaches. However, most of the researchers do not express their attitude towards attracting quantitative or qualitative FDI flows. In many cases, both quantitative and qualitative approaches are integrated and applied together. Scientists Wei and Andresso-O'Callaghan (2008) explore a regional FDI policy, which as an object of research might be defined as a quantitative model of the FDI policy. However, the factors determining the effectiveness of FDI policy (FDI/ GDP in specific region, education level, comparative advantage of export, efficiency of wages) are broadly in line with the quantitative model of the FDI policy. These researchers for this study choose the Euclidean distance model and the linear regression method. Cooray et al. (2014), analysing the drivers for liberalising of the FDI policy, use spatial econometric estimation for the panel dataset of 148 developed and developing countries. This model might be characterised as quantitative as these scientists focus on the liberalising regulatory framework and the use of the "open-door" approach. They claim that due to data limitation, it is difficult to identify whether countries tend to compete for different types of FDI. Therefore, designing FDI policy requires detailed and precise assessment of various factors, which are interfaced by attraction of foreign capital. However, a significant number of factors complicates formation of the FDI policy. For this reason, it is necessary to create hierarchy systems of factors that enable decision-makers to take a deeper look at the problem. For creating hierarchies and such an analysis of factors, the most suitable methods are multi-criteria decision making methods (MCDM). Although, these methods are adopted in various areas, determining qualitative incentives to attract FDI, the most suitable method is yet to be selected. Scientific literature (Zavadskas et al. 2014; Peng, Tzeng 2013) broadly classifies MCDM 
methods into two categories: discrete MCDM or discrete MADM (Multi-Attribute Decision Making) and continuous MODM (Multi-Objective Decision Making) methods. Zavadskas et al. (2014) divide MCDM into four groups:

1. Methods based for quantitative measurements. In this case, every alternative is estimated in quantitative methods and differences between these dimensions are evaluated (Ginevičius, Podvezko 2008);

2. Qualitative methods that are based on the opinion of experts allow determining the best alternative or several alternatives;

3. Comparative preference methods;

4. Methods which are based on qualitative measurements without using quantitative measures. This group involves verbal methods, which are applied under the high degree of uncertainty.

ANP and AHP methods are widely used in making decisions on strategic issues (Ergu et al. 2014; Lee 2013; Kahraman et al. 2013; Saaty 2005). Wind and Saaty (1980) apply the AHP method to create and evaluate a marketing strategy. Therefore, it does not allow evaluating inner-relationships between sub-factors and alternatives. Later, Saaty (1997) modified AHP and proposed the ANP method. He noticed that in these days, simple hierarchic structures are constructed of a goal, criteria and alternatives are mainly used by decision-makers who tend to simplify the complexity of a problem. Solutions are acquired from multilevel and simple hierarchy structure may differ. Even though, solutions acquired from more complicated hierarchies and networks may be completely different (Saaty 2006). Nevertheless, Saaty $(2005,2006)$ maintains that decision-makers tend to escape difficult hierarchy and simplify them; ANP is widespread in the scientific literature.

To sum up, the presumption can be made that it is appropriate to apply a multi-criteria decision making method for forming a FDI policy. The authors apply the ANP method, which enables them to assess both external and internal relationships of the components of the same criterion.

\subsection{BOCR analysis as a basis for creating criteria system}

BOCR analysis is often considered as a narrow financial tool. However, this underestimates its versatility in addressing intangible values. Hence, benefit-cost analysis may be defined as a decision-making tool that may be adopted in various areas. New factors, such as opportunities and risks, extend this analysis for estimating future outcomes of the project (strategy, policy or scheme). In addition, it allows evaluating two or more alternative projects at the same time. Opportunities usually catch expectations about positive spin-off projects and revenues in the future, while benefits represent current revenues or those profits from positive developments (Ergu et al. 2014). Risks in BOCR analysis are linked to the expected negative consequences in the future, during the development of a project. Although, a profit is frequently associated with company's benefit at the end of a financial year, in the case of a FDI policy formation, it may be treated as financial and non-financial benefits received during the project implementation. A full BOCR analysis is similar to that of SWOT. Although, both of them are usually applied 
on the micro-level just for assessing internal and external factors that affect performance of a company. However, these analyses may be perfectly adopted for evaluation at the macro level. For example, while developing the strategy for Taiwanese biotech pharmaceutical industry, Lee (2013) applied the fuzzy ANP method and integrated the SWOT analysis, which forms the basis for determining the sub-criteria. The ANP method is also adapted for the assessment of investment risk and decision-making (Ergu et al. 2014). Shiue and Lin (2012) apply ANP under BOCR basis for evaluating the optimal recycling strategy in the solar energy industry. The authors of the article propose to divide benefits into political, economic, social and technological. These four groups of factors may also be used to evaluate opportunities and costs.

\section{Methodology}

The ANP method is applied in five steps. The first step is composition of the criteria system, identification of sub-criteria on BOCR basis and presentation of alternatives.

The second step is devoted for identifying significance index through pair-wise comparison and calculation of the priority vector. The ANP method is based on the matrix of pair-wise comparison. The 1-9 point scale (Table 1) is used for the pair-wise comparison, where 1 refers to two factors of equal importance, and 9 refers to the other factor of full importance (Saaty 1980). The elements are evaluated in respect of the aim, and later, sub-criteria are assessed in respect of the aim and with each other by applying the comparative method in each group.

Table 1. Description of the pair-wise comparison scale

\begin{tabular}{cll}
\hline $\begin{array}{c}\text { Intensity of } \\
\text { importance }\end{array}$ & \multicolumn{1}{c}{ Definition } & \multicolumn{1}{c}{ Description } \\
\hline 1 & Equal importance & Two activities contribute equally to the objective \\
\hline 3 & Moderate importance & $\begin{array}{l}\text { Experience and judgment slightly favour one over } \\
\text { another }\end{array}$ \\
\hline 5 & Strong importance & $\begin{array}{l}\text { Experience and judgment strongly favour one over } \\
\text { another }\end{array}$ \\
\hline 7 & $\begin{array}{l}\text { Very strong demonstrated } \\
\text { importance }\end{array}$ & $\begin{array}{l}\text { An activity is favoured very strongly over another; } \\
\text { its dominance demonstrated in practice }\end{array}$ \\
\hline $2,4,6,8$ & $\begin{array}{l}\text { For compromise between } \\
\text { the above values }\end{array}$ & $\begin{array}{l}\text { The evidence favouring one activity over another is } \\
\text { of the highest possible order of affirmation }\end{array}$ \\
\hline $\begin{array}{l}\text { Sometimes one needs to interpolate a compromise } \\
\text { judgment numerically because there is no good } \\
\text { word to describe it }\end{array}$ \\
\hline
\end{tabular}

Source: Saaty (1980).

Experts evaluate importance of every factor that is the dominance over the other. Coefficient $a_{i j}$ symbolises the importance of the component $i$ (row) over the component $j$ (column): 


$$
a_{i j}=\frac{w_{i}}{w_{j}} .
$$

After completion of the matrix $A$, an estimate of the relative importance of the elements compared is calculated using formula 3 . To form the initial super matrix, then $w$ is normalised to define the local priority vector (Ergu et al. 2014) (2) and (3):

$$
\begin{gathered}
A \cdot w=\lambda_{\max } \cdot w \\
A=\left[\begin{array}{ccc}
W_{1} / W_{1} & \cdots & W_{1} / W_{n} \\
\cdots & \cdots & \cdots \\
W_{n} / W_{1} & \cdots & W_{n} / W_{n}
\end{array}\right]=\left[\begin{array}{ccc}
1 & \cdots & a_{1 n} \\
\cdots & \cdots & \cdots \\
1 / a_{n} & \cdots & 1
\end{array}\right],
\end{gathered}
$$

where: $A$ - pair-wise comparison matrix; $\lambda_{\max }$ - the maximum eigenvalue of the matrix $A ; w$ - eigenvector.

In the third step, the consistency index CI (4) and the consistency coefficient CR (5) are calculated. These two parameters define the reliability of the model:

$$
\begin{gathered}
C I=\left(\lambda_{\text {max }}-n\right) /(n-1), \\
C R=\frac{C I}{R I}=\frac{\left(\lambda_{\text {max }}-n\right) /(n-1)}{R I} .
\end{gathered}
$$

When the value of the consistency coefficient CR is lower than 0.1 , the matrix satisfies the condition (Table 2). If the matrix consistency test fail, incompatible elements should be identified and reviewed. Otherwise, the final results will be unreliable (Ergu et al. 2014). $\mathrm{R}$ is the average random index, which is based on the matrix size; $n$ is the number of factors (Saaty 2005).

Table 2. The average random index

\begin{tabular}{ccccccccccc}
\hline$n$ & 1 & 2 & 3 & 4 & 5 & 6 & 7 & 8 & 9 & 10 \\
\hline$R I$ & 0 & 0 & 0.52 & 0.89 & 1.11 & 1.25 & 1.35 & 1.4 & 1.45 & 1.49 \\
\hline
\end{tabular}

Source: Shiue, Lin (2012).

In the fourth step, the supermatrix is constructed. The weights in the supermatrix (6) show the interactions in the system. To obtain global priorities in a system with interdependent influences, the local priority vectors are entered in the appropriate columns of a matrix, known as the supermatrix. As a result, the supermatrix is actually a partitioned matrix, where each matrix segment represents a relationship between two nodes (components or clusters) in a system. The standard supermatrix is in formula 7 . The components of a decision system are $C_{n}$ which have $N$ clusters; $e_{N n}$ denotes $n$ - element in $N$ - cluster $N_{i j}$ is a block matrix, which is composed of weights of priority vectors $w$. In the ANP, if a comparison matrix passes the consistency test, the priorities that are derived from the comparison matrix are added as parts of the columns of the supermatrix of a network. Otherwise, this comparison matrix has to be revised by experts. Therefore, 
the consistency tests will be much more complicated in the ANP case than in the AHP, since there are more comparison matrices in the ANP, which can be derived from the following supermatrix of a network:

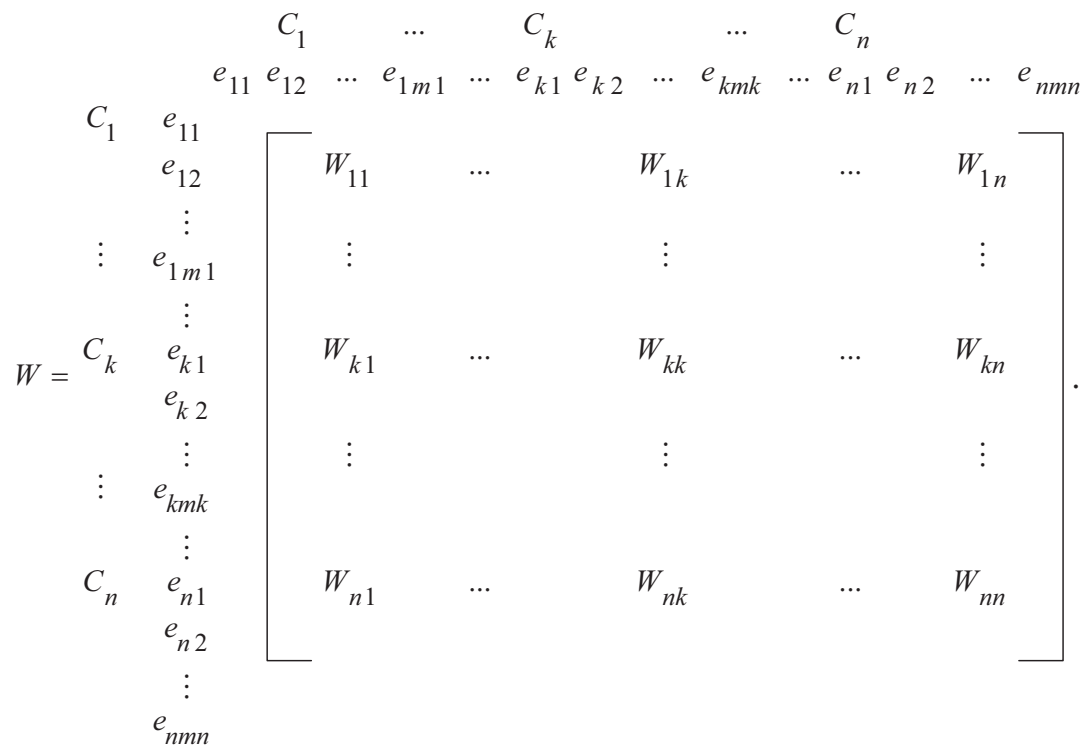

The fifth step is selection of alternatives. The authors of the article propose four alternatives for the formation of a comprehensive FDI policy: the FDI policy directed to R\&D; the FDI policy directed to the service sector; the FDI policy directed to export; the FDI policy directed to the improvement of the investment environment.

For making the final decision, Wijnmalen (2007) recommends to employ five different synthesis methods: additive (7), probabilistic additive (8) subtractive (9), multiplicative (10), and multiplicative priority powers (11).

Additive method:

$$
P_{i}=b B_{i}+o O_{i}+c\left[\left(1 / C_{i}\right)_{\text {normalized }}\right]+r\left[\left(1 / R_{i}\right)_{\text {normalized }}\right],
$$

probabilistic additive:

$$
P_{i}=b B_{i}+o O_{i}+c\left(1-C_{i}\right)+r\left(1-R_{i}\right)
$$

subtractive:

$$
P_{i}=b B_{i}+o O_{i}-c C_{i}-r R_{i}
$$

multiplicative priority powers:

multiplicative:

$$
P_{i}=B_{i}^{b} O_{i}^{o}\left[\left(1 / C_{i}\right)_{\text {normalized }}\right]^{c}\left[\left(1 / R_{i}\right)_{\text {normalized }}\right]^{r},
$$

$$
P_{i}=\frac{B_{i} O_{i}}{C_{i} R_{i}},
$$

where $b, o, c, r$ are normalized weights of merit $\mathrm{B}, \mathrm{O}, \mathrm{C}$ and $\mathrm{R}$, respectively; $B_{i}, O_{i}, C_{i}$ and $R_{i}$ represent the synthesized results of the alternative $i$ under merit $\mathrm{B}, \mathrm{O}, \mathrm{C}$ and $\mathrm{R}$. 


\section{Case study}

The entire ANP model consists of a two level decision-making network (Fig. 1). The top-level structure has four merits Benefit-Opportunities-Costs-Risks. The subnets under each of the four BOCR merits are composed of their respective clusters and elements. The goal of the model is to select the best FDI policy for Lithuania. The strategic criteria are created along with the goal. They are: high quality foreign direct investment, development of human resource capital and the complex development of production factors. The authors of the article do not set strategic sub-criteria. The strategic criteria are interpreted as follow:

1. The high quality investment is determined as an investment that creates jobs, which require high-qualified labour force, transfer of knowledge, upgraded technologies and promotes high-tech;

2. The development of human resource capital refers to the development of competence, knowledge and skill of groups of working people;

3. The complex development of the production factors. The classical or quantitative production factors cover land, capital and labour force. Meanwhile, the authors of the article focus on the qualitative FDI policy approach, which defines the following production factors: human capital, knowledge and infrastructure.

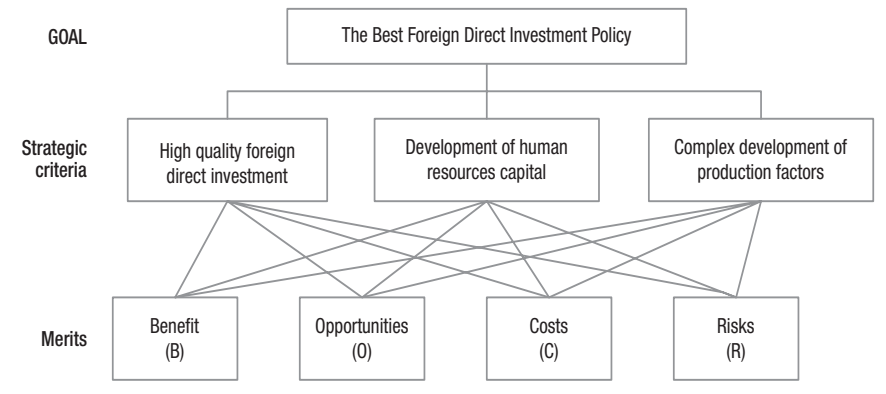

Fig. 1. The control hierarchy Source: compiled by the authors.

\subsection{Benefits model}

The perspective of benefits (Fig. 2) is comprised of political, economic, social and technological benefits obtained from implementing the FDI policy. Political benefits cover the increase of international competitiveness, the increase in political stability and the growth of wages. However, most of countries forming their FDI policy focus on economic benefits. Although, scientific literature emphasises creation of new jobs, in this case, the authors of the article define other supplementary economic benefits: improved quality of life, closing of the gap between high-income and middle-class groups, decline in regional exclusion and creation of new jobs. Social benefits are closely related to economic ones, especially, the growth of emotional satisfaction that arises from the improved quality of life. Tolerance toward other cultures refers to the increasing number of foreign employees and employers that allows cognizing businesses and cultural features. Technological benefits are particularly important in the research and development 


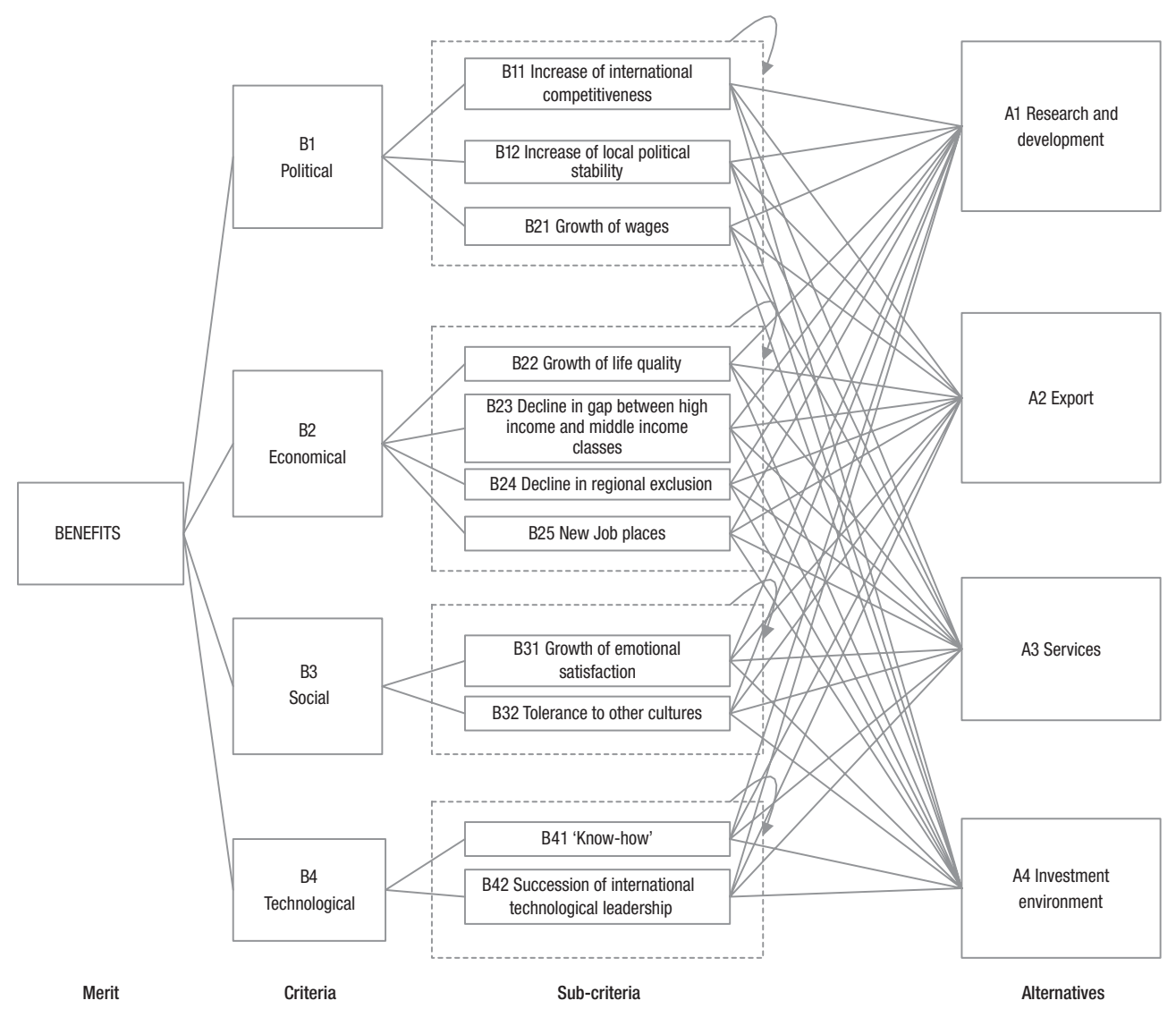

Fig. 2. Benefit sub-network

Source: compiled by the authors.

area. Even more, local companies "copy" technologies from MNCs and adopt them in their own businesses. These sub-criteria are determined in respect to strategic goals. In addition, all benefits may be achieved implementing a particular FDI policy. The ANP method, as it was mentioned above, enables to evaluate inner-relationship and dependence between sub-criteria in respect of alternative FDI policies. In addition, the semicircular arrows along the section of sub-criteria graphically indicate the sub-network. In order to determine the inner dependence between sub-criteria, and to compare criteria priorities, the survey was carried out during which eight experts were interviewed. The results show that technological benefits are the most important in forming a FDI policy (Table 3).

The matrix has passed consistency index CI and consistency coefficient CR tests, thus, the authors of the article formed the supermatrix and the priorities of sub-criteria and criteria were obtained (Table 4).

Despite, the fact, that the technological benefits are the most important achieving the strategic goals, the results reveal that attracting MNCs in R\&D would give more political benefits than others (Table 5). 
A. Simelytè et al. Analytical network process based on BOCR analysis as an approach for designing ...

Table 3. Pair-wise comparison and determination of priorities in the line with the benefit merit

\begin{tabular}{lcccccc}
\hline & $\begin{array}{c}\text { B1 } \\
\text { Political }\end{array}$ & $\begin{array}{c}\text { B2 } \\
\text { Economic }\end{array}$ & $\begin{array}{c}\text { B3 } \\
\text { Social }\end{array}$ & $\begin{array}{c}\text { B4 } \\
\text { Technological }\end{array}$ & Normalized & Rank \\
\hline B2 Economic & 2 & 1.0 & 2 & $1 / 2$ & 0.271 & 2 \\
\hline B1 Political & 1.0 & $1 / 2$ & 2 & $1 / 2$ & 0.191 & 3 \\
\hline B3 Social & $1 / 2$ & $1 / 2$ & 1.0 & $1 / 3$ & 0.120 & 4 \\
\hline B4 Technological & 2.0 & 2.0 & 3.0 & 1.0 & 0.418 & 1 \\
\hline
\end{tabular}

Table 4. Priorities of the elements in the benefit sub-network

\begin{tabular}{lcc}
\hline \multicolumn{1}{c}{ Name } & $\begin{array}{c}\text { Normalized } \\
\text { by cluster }\end{array}$ & Limiting \\
\hline B1 Political control sub-criteria & $\mathbf{0 . 3 5 1}$ & 0.098 \\
\hline B11 Increase of international competitiveness & 0.667 & 0.018 \\
\hline B12 Increase of local political stability & 0.333 & 0.008 \\
\hline B2 Economic control sub-criteria & $\mathbf{0 . 2 1 3}$ & 0.059 \\
\hline B21 Growth of wages & 0.128 & 0.045 \\
\hline B22 Growth of life quality & 0.170 & 0.060 \\
\hline B23 Decline in gap between high income and middle income classes & 0.179 & 0.063 \\
\hline B24 Decline in regional exclusion & 0.203 & 0.007 \\
\hline B25 New Job places & 0.319 & 0.011 \\
\hline B3 Social control sub-criteria & $\mathbf{0 . 1 6 1}$ & 0.045 \\
\hline B31 Growth of emotional satisfaction & 0.800 & 0.008 \\
\hline B32 Tolerance to other cultures & 0.200 & 0.002 \\
\hline B4 Technological control sub-criteria & $\mathbf{0 . 2 7 5}$ & 0.077 \\
\hline B41 'Know-how' & 0.750 & 0.011 \\
\hline B42 Succession of international technological leadership & 0.250 & 0.036 \\
\hline
\end{tabular}

Table 5. Prioritization of the alternatives under benefit network

\begin{tabular}{lcc}
\hline & Normalized by cluster & Rank \\
\hline A1 Export & 0.204 & 3 \\
\hline A2 Investment environment & 0.261 & 2 \\
\hline A3 Research and development & 0.335 & 1 \\
\hline A4 Services & 0.199 & 4 \\
\hline
\end{tabular}

Especially, it would increase international competitiveness in the same geographical area. Although, attraction of FDI into research and development area would bring great benefits for Lithuania, final results may be different. 


\subsection{Opportunities model}

The perspective of opportunities (Fig. 3) is similar to that of benefits. Moreover, sub-networks of benefits and opportunities are closely related. For example, one of the political benefits - improved international competitiveness - causes the change in international image and international recognition. Some countries use the image of a reputable company, which operates in the local market. Implementing its FDI policy and attracting FDI, the host country would obtain such economic opportunities: the growth of export in innovative business sectors, the increase in labour productivity, the growth of international trade, the growth of inward FDI, the growth of traditional business sectors and reinvestment. The first one mentioned is closely related to the technological benefits as well as technological opportunities. Meanwhile, one of the social opportunities is the decrease in emigration, which would result from improving the quality of life.

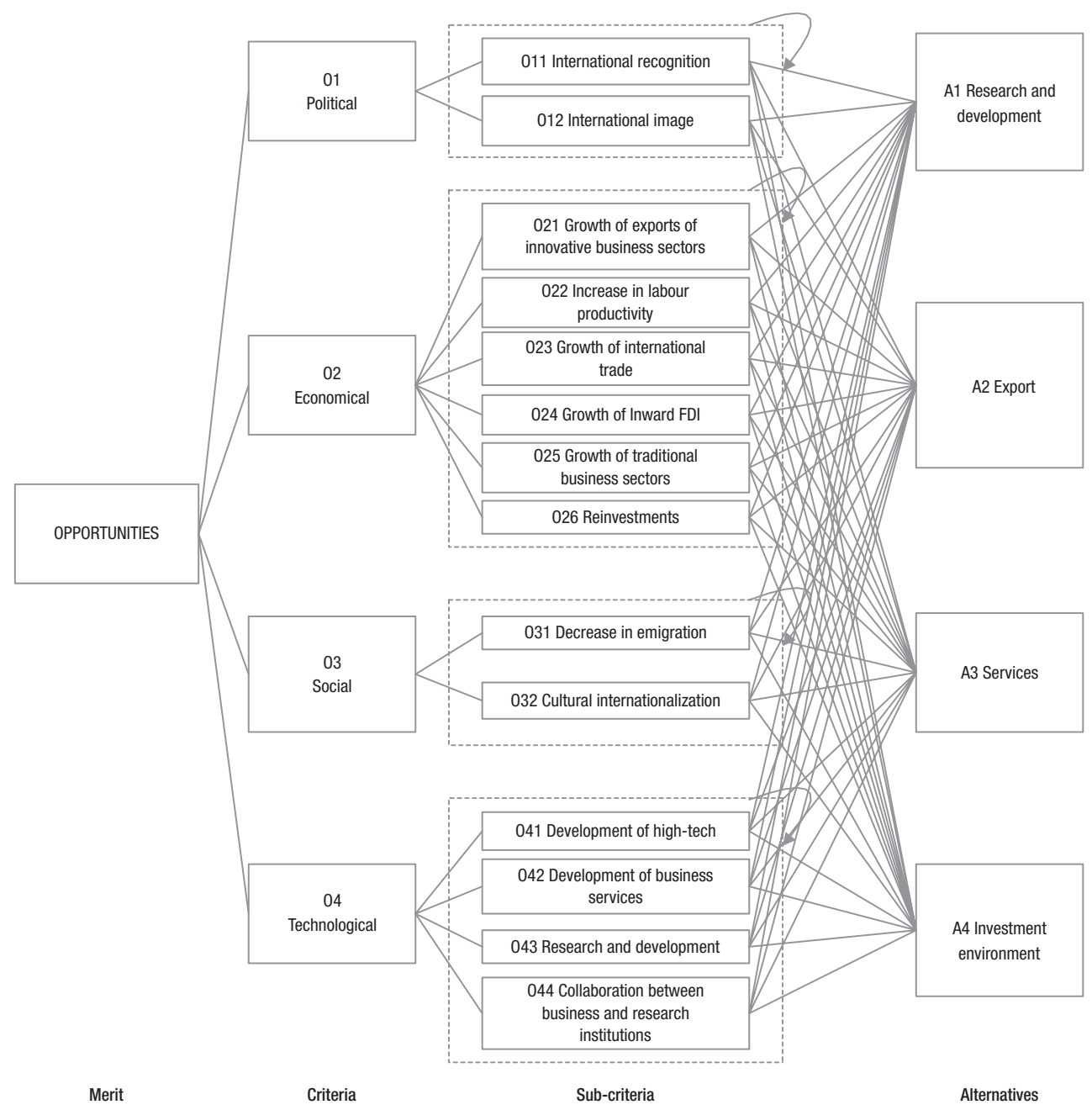

Fig. 3. Opportunity sub-network

Source: compiled by the authors. 
As in the benefit sub-network, the matrix has passed consistency index CI and consistency coefficient CR tests, thus the priorities of the elements in opportunity sub-network were calculated (Tables 6 and 7).

The results in the opportunity sub-network confirm that Lithuania would succeed in forming the FDI policy oriented towards the research and development (Table 8). In addition, the technological opportunities might be exploited. It would lead to the growth of export in innovative business sectors. Although, the benefits approve the opportunities, the costs and risks supposed to be evaluated regarding FDI attraction into R\&D sectors.

Table 6. Pair-wise comparison and determination of priorities in the line with the opportunities merit

\begin{tabular}{lcccccc}
\hline & $\begin{array}{c}\text { O1 } \\
\text { Political }\end{array}$ & $\begin{array}{c}\text { O2 } \\
\text { Economic }\end{array}$ & $\begin{array}{c}\text { O3 } \\
\text { Social }\end{array}$ & $\begin{array}{c}\text { O4 } \\
\text { Technological }\end{array}$ & Normalized & Rank \\
\hline O1 Political & 1.0 & $1 / 2$ & 1.0 & $1 / 3$ & 0.142 & 3 \\
\hline O2 Economic & 2.0 & 1.0 & 3 & 1.0 & 0.348 & 2 \\
\hline O3 Social & 1.0 & $1 / 3$ & 1.0 & $1 / 3$ & 0.128 & 4 \\
\hline O4 Technological & 3.0 & 1.0 & 3 & 1.0 & 0.383 & 1 \\
\hline
\end{tabular}

Table 7. Priorities of the elements in the opportunity sub-network

\begin{tabular}{lcc}
\hline \multicolumn{1}{c}{ Name } & Normalized by cluster & Limiting \\
\hline \multicolumn{1}{c}{ O1 Political control sub-criteria } & $\mathbf{0 . 1 7 8}$ & 0.057 \\
\hline O11 International recognition & 0.500 & 0.007 \\
\hline O12 International image & 0.500 & 0.007 \\
\hline \multicolumn{1}{c}{ O2 Economic control sub-criteria } & $\mathbf{0 . 3 2 1}$ & 0.103 \\
\hline O21 Growth of exports of innovative business sectors & 0.295 & 0.018 \\
\hline O22 Increase in labour productivity & 0.115 & 0.005 \\
\hline O23 Growth of international trade & 0.118 & 0.005 \\
\hline O24 Growth of inward FDI & 0.148 & 0.006 \\
\hline O25 Growth of traditional business sectors & 0.122 & 0.005 \\
\hline O26 Reinvestments & 0.202 & 0.008 \\
\hline \multicolumn{1}{c}{ O3 Social control sub-criteria } & $\mathbf{0 . 1 4 5}$ & 0.046 \\
\hline O31 Decrease in emigration & 0.50 & 0.004 \\
\hline O32 Cultural internationalization & 0.50 & 0.004 \\
\hline \multicolumn{1}{c}{ O4 Technological control sub-criteria } & $\mathbf{0 . 3 5 6}$ & 0.114 \\
\hline O41 Development of high-tech & 0.286 & 0.014 \\
\hline O42 Development of business services & 0.143 & 0.007 \\
\hline O43 Research and development & 0.286 & 0.014 \\
\hline O44 Collaboration between business and research institutions & 0.286 & 0.014 \\
\hline
\end{tabular}


Table 8. Prioritization of the alternatives under opportunity sub-network

\begin{tabular}{lcc}
\hline & Normalized by cluster & Rank \\
\hline A1 Export & 0.167 & 4 \\
\hline A2 Investment environment & 0.255 & 2 \\
\hline A3 Research and development & 0.365 & 1 \\
\hline A4 Services & 0.213 & 3 \\
\hline
\end{tabular}

\subsection{Costs model}

The sub-network of costs (Fig. 4) differs from benefits and opportunities in respect of criteria. The social and technological criteria were replaced to financial and international ones. Although, the international and financial costs look similar, the financial costs

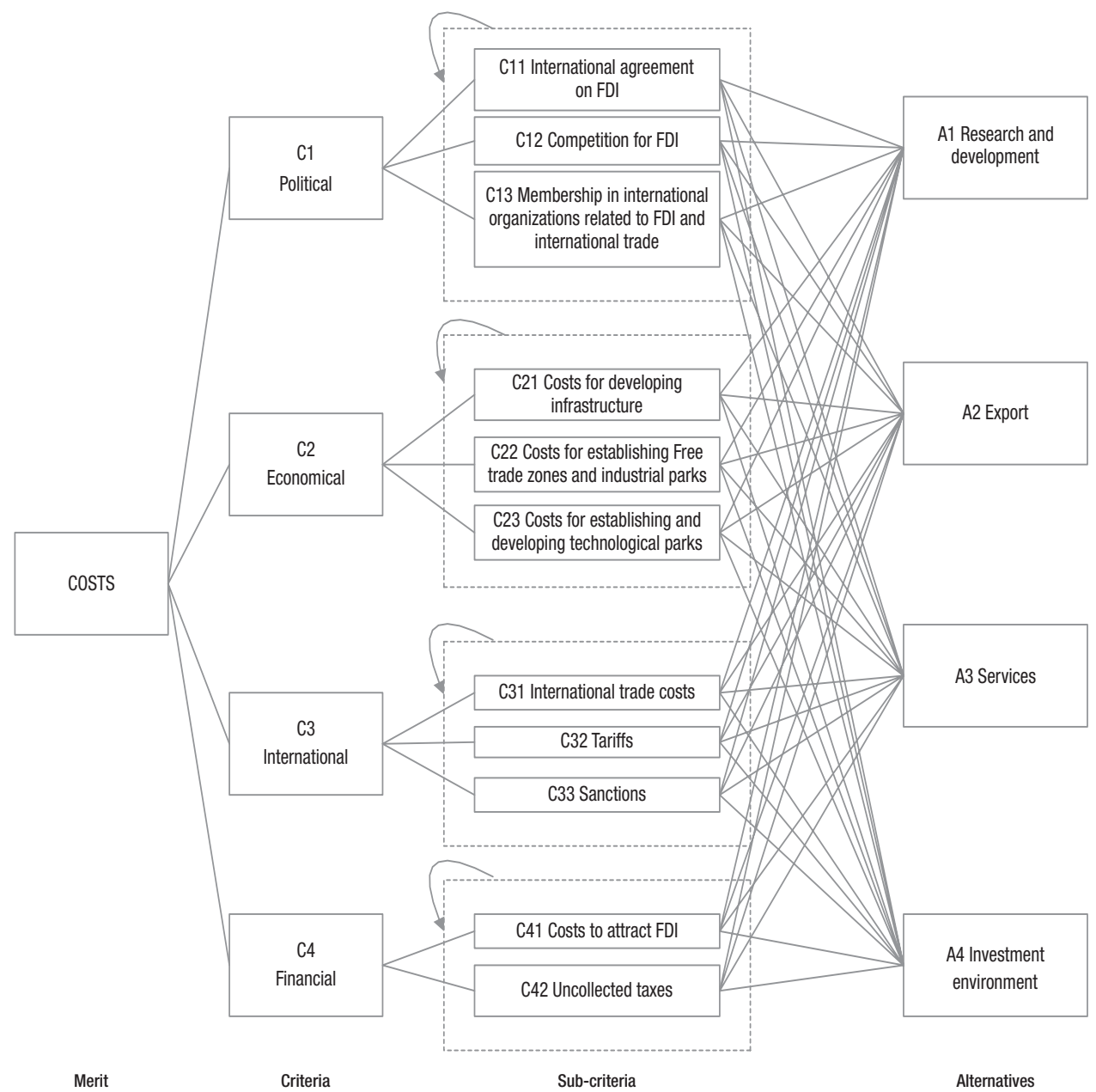

Fig. 4. Cost sub-network

Source: compiled by the authors. 
mostly refer to the local rather than international market. The costs to attract FDI cover subsidies and financial support. Meanwhile, the uncollected taxes are associated with tax holidays. Other groups of criteria are in the line with the benefits and the opportunities.

The matrix has passed consistency index CI and consistency coefficient CR tests; thus, priorities of the elements in the cost sub-network and the prioritization of the alternatives under the cost sub-network were evaluated (Tables 9 and 10).

The results reveal that the highest costs would be generated while implementing the FDI policy targeted at R\&D and the lowest - towards service businesses (Table 11). It is determined by high cost of international trade and international agreements. Nevertheless, Lithuania would benefit and exploit opportunities in developing the FDI policy towards R\&D and would also have significant costs.

Table 9. Pair-wise comparison and determination of priorities in the line with the costs merit

\begin{tabular}{lcccccc}
\hline & $\begin{array}{c}\mathrm{C} 1 \\
\text { Political }\end{array}$ & $\begin{array}{c}\mathrm{C} 2 \\
\text { Economic }\end{array}$ & $\begin{array}{c}\mathrm{C} 3 \\
\text { International }\end{array}$ & $\begin{array}{c}\mathrm{C} 4 \\
\text { Financial }\end{array}$ & Normalized & Rank \\
\hline C1 Political & 1.0 & 4 & 1.0 & 2 & 0.360 & 2 \\
\hline C2 Economic & $1 / 4$ & 1.0 & $1 / 3$ & $1 / 2$ & 0.098 & 4 \\
\hline C3 International & 1.0 & 3.0 & 1.0 & 3 & 0.377 & 1 \\
\hline C4 Financial & $1 / 2$ & 2.0 & $1 / 3$ & 1.0 & 0.165 & 3 \\
\hline
\end{tabular}

Table 10. Priorities of the elements in the cost sub-network

\begin{tabular}{lcc}
\hline \multicolumn{1}{c}{ Name } & $\begin{array}{c}\text { Normalized by } \\
\text { cluster }\end{array}$ & Limiting \\
\hline C1 Political control sub-criteria & $\mathbf{0 . 2 7 5}$ & 0.08 \\
\hline C11 International agreement on FDI & 0.332 & 0.013 \\
\hline C12 Competition for FDI & 0.139 & 0.006 \\
\hline C13 Membership in international organisations related to FDI & 0.528 & 0.021 \\
and international trade & & \\
\hline C2 Economic control sub-criteria & $\mathbf{0 . 2 1 9}$ & 0.07 \\
\hline C21 Costs for establishing and developing technological parks & 0.400 & 0.008 \\
\hline C22 Costs for developing infrastructure & 0.200 & 0.004 \\
\hline C23 Costs for establishing Free trade zones and industrial parks & 0.400 & 0.008 \\
\hline C3 International control sub-criteria & $\mathbf{0 . 3 3 4}$ & 0.107 \\
\hline C31 International trade costs & 0.413 & 0.021 \\
\hline C32 Tariffs & 0.259 & 0.013 \\
\hline C33 Sanctions & 0.327 & 0.018 \\
\hline C4 Financial control sub-criteria & $\mathbf{0 . 1 7 1}$ & 0.054 \\
\hline C41 Costs to attract FDI & 0.500 & 0.006 \\
\hline C42 Uncollected taxes & 0.500 & 0.006 \\
\hline
\end{tabular}


Table 11. Prioritization of the alternatives under the cost sub-network

\begin{tabular}{lcc}
\hline & Normalized by cluster & Limiting \\
\hline A1 Export & 0.232 & 3 \\
\hline A2 Investment environment & 0.258 & 2 \\
\hline A3 Research and development & 0.319 & 1 \\
\hline A4 Services & 0.191 & 4 \\
\hline
\end{tabular}

\subsection{Risks model}

The risk sub-network (Fig. 5) covers six groups of criteria. The failure to manage the FDI policy and environmental risks are included additionally. The first one is introduced as Lithuania has failed in managing several strategic projects. Furthermore, the situati-

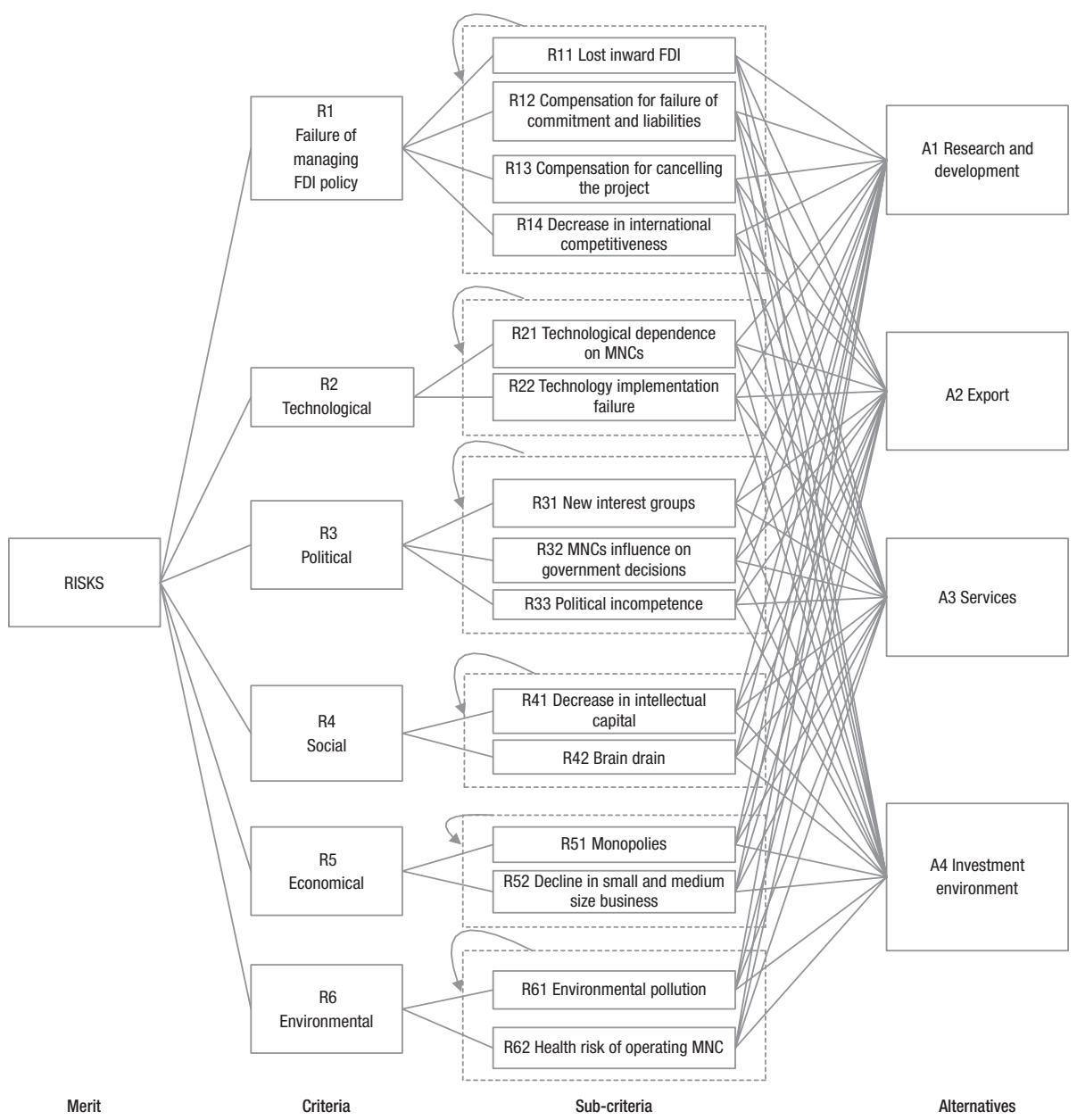

Fig. 5. Risk sub-network

Source: compiled by the authors. 
ons like these cause many negative consequences, especially financial ones. These are the compensation for failure of commitment and liabilities and compensation for cancelling the project. Both of them have a strong inner-relationship with the loss of inward FDI, which determines decrease in international competiveness. The environmental risks appear from MNCs established in the manufacturing area.

According to the results (Table 12), the failure to manage FDI projects has the highest risk in achieving strategic goals. Furthermore, political risks are closely related to the first group of criteria as the rate differs by 0.02 points.

However, Lithuania (Table 13 and Table 14) may face these risks while implementing the FDI policy towards MNCs companies that are interested in expanding their exports. The FDI policy towards service sectors would cause the least amount of risks.

The authors of the article obtained final results following the methodology. The final synthesis (Table 15) reveals that the most appropriate FDI policy for Lithuania, which would enable to achieve or partly achieve strategic goals and to avoid risks.

Table 12. Pair-wise comparison and determination of priorities in the line with the risk merit

\begin{tabular}{lcccccccc}
\hline & $\begin{array}{c}\text { R1 Failure } \\
\text { to manage } \\
\text { the FDI } \\
\text { policy }\end{array}$ & $\begin{array}{c}\text { R2 } \\
\text { Techno- } \\
\text { logical }\end{array}$ & $\begin{array}{c}\text { R3 } \\
\text { Political }\end{array}$ & $\begin{array}{c}\text { R4 } \\
\text { Social }\end{array}$ & $\begin{array}{c}\text { R5 } \\
\text { Econo- } \\
\text { mic }\end{array}$ & $\begin{array}{c}\text { R6 } \\
\text { Enviro- } \\
\text { nmental }\end{array}$ & $\begin{array}{c}\text { Norma- Rank } \\
\text { lized }\end{array}$ & \\
\hline $\begin{array}{l}\text { R1 Failure to } \\
\text { manage the FDI } \\
\text { policy }\end{array}$ & 1.0 & 4 & 1.0 & 2 & 1.0 & 3 & 0.253 & 1 \\
\hline R2 Technological & $1 / 4$ & 1.0 & $1 / 3$ & 1.0 & $1 / 2$ & 3 & 0.106 & 5 \\
\hline R3 Political & 1.0 & 3.0 & 1.0 & 3 & 1.0 & 3 & 0.251 & 2 \\
\hline R4 Social risk & $1 / 2$ & 1.0 & $1 / 3$ & 1.0 & $1 / 2$ & 2 & 0.108 & 4 \\
\hline R5 Economic & 1.0 & 2.0 & 1.0 & 2.0 & 1.0 & 3 & 0.217 & 3 \\
\hline R6 Environmental & $1 / 3$ & $1 / 3$ & $1 / 3$ & $1 / 2$ & $1 / 3$ & 1.0 & 0.064 & 6 \\
\hline
\end{tabular}

Table 13. Priorities of the elements in the risk sub-network

\begin{tabular}{|c|c|c|}
\hline Name & Normalized by cluster & Limiting \\
\hline R1 Failure of managing FDI policy & 0.258 & 0.033 \\
\hline R11 Lost inward FDI & 0.216 & 0.028 \\
\hline R12 Compensation for failure of commitment and liabilities & 0.199 & 0.026 \\
\hline R13 Compensation for cancelling the project & 0.201 & 0.026 \\
\hline R14 Decrease in international competitiveness & 0.384 & 0.050 \\
\hline R2 Technological risk & 0.115 & 0.015 \\
\hline R21 Technological dependence on MNCs & 0.692 & 0.023 \\
\hline R22 Technology implementation failure & 0.308 & 0.010 \\
\hline
\end{tabular}


End of Table 13

\begin{tabular}{lll}
\hline \multicolumn{1}{c}{ Name } & Normalized by cluster & Limiting \\
\hline R3 Political risk & $\mathbf{0 . 2 2 8}$ & 0.029 \\
\hline R31 New interest groups & 0.580 & 0.059 \\
\hline R32 MNCs influence on government decisions & 0.316 & 0.032 \\
\hline R33 Political incompetence & 0.104 & 0.011 \\
\hline R4 Social risk & $\mathbf{0 . 1 3 2}$ & 0.017 \\
\hline R41 Decrease in intellectual capital & 0.419 & 0.015 \\
\hline R42 Brain drain & 0.581 & 0.021 \\
\hline R5 Economic risk & $\mathbf{0 . 1 9 9}$ & 0.025 \\
\hline R51 Monopolies & 0.783 & 0.07 \\
\hline R52 Decline in small and medium size business & 0.217 & 0.02 \\
\hline R6 Environmental risk & $\mathbf{0 . 0 6 7}$ & 0.009 \\
\hline R61 Environmental pollution & 0.840 & 0.037 \\
\hline R62 Health risk of operating MNC & 0.160 & 0.007 \\
\hline
\end{tabular}

Table 14. Prioritization of the alternatives under the risk sub-network

\begin{tabular}{lcc}
\hline & Normalized by cluster & Limiting \\
\hline A1 Export & 0.293 & 1 \\
\hline A2 Investment environment & 0.278 & 2 \\
\hline A3 Research and development & 0.220 & 3 \\
\hline A4 Services & 0.209 & 4 \\
\hline
\end{tabular}

Table 15. Final results of synthesis

\begin{tabular}{lcccccc}
\hline & Additive & $\begin{array}{c}\text { Probabilistic } \\
\text { additive }\end{array}$ & $\begin{array}{c}\text { Subtrac- } \\
\text { tive }\end{array}$ & $\begin{array}{c}\text { Multiplicative } \\
\text { priority powers }\end{array}$ & $\begin{array}{c}\text { Multip- } \\
\text { licative }\end{array}$ & Average \\
\hline Priority & Priority & Priority & Priority & Priority & Priority \\
\hline $\begin{array}{l}\text { Research and } \\
\text { development }\end{array}$ & 0.3674 & 0.5982 & 0.0162 & 0.2292 & 8.4779 & 2.1942 \\
\hline Rank & 1 & 1 & 3 & 3 & 1 & 1 \\
\hline Export & 0.1839 & 0.4319 & 0.0251 & 0.2420 & 0.5000 & 0.2297 \\
\hline Rank & 4 & 4 & 2 & 1 & 4 & 3 \\
\hline Services & 0.3160 & 0.5647 & -0.0125 & 0.2417 & 4.3151 & 1.0268 \\
\hline Rank & 2 & 2 & 4 & 2 & 2 & 2 \\
\hline $\begin{array}{l}\text { Investment } \\
\text { environment }\end{array}$ & 0.2321 & 0.4870 & 0.1061 & 0.2280 & 1 & 0,2165 \\
\hline Rank & 3 & 3 & 1 & 4 & 3 & 4 \\
\hline
\end{tabular}


Although the risk is the highest in adopting the FDI policy directed towards R\&D, the final synthesis reveals that Lithuania would mostly benefit from this type of policy. In this case, risks are associated with possible failure of implementing the FDI policy, which may decrease the competitiveness on the global scale. On the other hand, successful implementation of targeted FDI policy towards R\&D would guarantee the growth of exports of innovative products, which positively affects the global competitiveness.

\section{Conclusions}

The issue of foreign direct investment has been intensively analysed since the 80 s when only the positive impact of FDI on a host country was perceived. However overtime, situation has changed; thus, the scientific literature raises the question regarding attracted FDI. However, the main problem for developing the framework for the FDI policy is to select the appropriate method and to create the methodology. Two complementary methods were applied in the article. The first one is BOCR; on its basis, the criteria system was formed. The second one is the multi-criteria decision making method ANP. This method is widely adopted in making of decisions on strategic issues. Its popularity might be explained by the fact, that the ANP method allows evaluating external and internal relationship of components of the same criterion. The authors propose the following alternatives for the FDI policy: the FDI policy targeted at service sectors; the FDI policy target at promotion of export; the FDI policy targeted at R\&D and the FDI policy targeted at improvement of the business environment. Final results demonstrate that Lithuania would achieve its strategic goals and benefit from implementing the FDI policy, which is targeted at research and development. However, its adoption would generated greater costs than others policies. Meanwhile, the FDI policy targeted at promotion if services would lead to lowest risks and costs compared to other policies. At the same time, it would give the least amount of benefits.

Generalizing, the results of the research indicate that attracting FDI to R\&D would be the most effective policy that would bring a positive long-term impact of FDI on economic development of the country.

\section{References}

Aurangzeb, Z.; Stengos, T. 2014. The role of foreign direct investment (FDI) in a dualistic growth framework: a smooth coefficient semi-parametric approach, Borsa Istanbul Review 14(3): 133-144. http://dx.doi.org/10.1016/j.bir.2014.06.004

Bjorvatn, K.; Eckel, C. 2006. Policy competition for foreign direct investment between asymmetric countries, European Economic Review 50(7): 1891-1907.

http://dx.doi.org/10.1016/j.euroecorev.2005.07.002

Belloumi, M. 2014. The relationship between trade, FDI and economic growth in Tunisia: an application of the autoregressive distributed lag model, Economic Systems 38: 269-287.

http://dx.doi.org/10.1016/j.ecosys.2013.09.002

Cooray, A.; Tamarian, A.; Vadlamannati, C. K. 2014. What drives FDI policy liberalization? An empirical investigation, Regional and Urban Economics. http://dx.doi.org/10.1016/j.regsciurbeco.2014.06.008 
Du, L.; Harrison, A.; Jefferson, G. 2014. FDI spillovers and industrial policy, World Development 64: 366-383. http://dx.doi.org/10.1016/j.worlddev.2014.06.005

Ergu, D.; Kou, G.; Sh, Y. 2014. Analytic network process in risk assessment and decision analysis, Computers and Operations Research 42(2): 58-74. http://dx.doi.org/10.1016/j.cor.2011.03.005

Fenny, S.; Iamsiraroj, S. McGillivray, M. 2014. Growth and foreign direct investment in Pacific Island countries, Economic Modelling 37(February): 332-339.

http://dx.doi.org/10.1016/j.econmod.2013.11.018

Filippov, S.; Costa, I. 2007. Redefining foreign direct investment policy: a two dimensional framework, UNU-MERIT Working Paper 2007-029, Maastricht.

Ginevičius, R.; Podvezko, V. 2008. Daugiakriterinio vertinimo taikymo galimybès kiekybiniams socialinių reikšmių vertinimui, Verslas: teorija ir praktika [Business: Thoery and Practice] 9(2): 81-87. http://dx.doi.org/10.3846/1648-0627.2008.9.81-87

Gui-Diby, S. L. 2014. Impact of foreign direct investments on economic growth in Africa: evidence from three decades of panel data analyses, Research in Economics 68: 248-256.

http://dx.doi.org/10.1016/j.rie.2014.04.003

Kahraman, C.; Suder, A.; Cebi, S. 2013. Fuzzy multi-criteria and multi-experts evaluation in higher education: the case of Turkey, Technological and Economic Development of Economy 19(4): 549-569. http://dx.doi.org/10.3846/20294913.2013.837110

Lee, Y. H. 2013. Application of a SWOT-FANP method, Technological and Economic Development of Economy 19(4): 570-592. http://dx.doi.org/10.3846/20294913.2013.837111

Long, Ch.; Yang, J.; Zhang, J. 2015. Institutional impact of foreign direct investment in China, World Development 66: 31-48. http://dx.doi.org/10.1016/j.worlddev.2014.08.001

Markusen, J. R. 2013. Expansion of trade at the extensive margin: a general gains-from-trade result and illustrative example, Journal of International Economics 89(1): 262-270.

http://dx.doi.org/10.1016/j.jinteco.2012.04.007

Medvedev, D. 2010. Preferential trade agreements and their role in world trade, Review of World Economy 146(2): 199-222. http://dx.doi.org/10.1007/s10290-010-0054-x

Merlevede, B.; Schoors, K.; Spartareanu, M. 2014. FDI spillovers and time since foreign entry, World Development 56: 108-126. http://dx.doi.org/10.1016/j.worlddev.2013.10.022

Peng, K. H.; Tzeng, G. H. 2013. A hybrid dynamic MADM model for problem improvement in economics and business, Technological and Economic Development of Economy 19(4): 638-660. http://dx.doi.org/10.3846/20294913.2013.837114

Saaty, T. L. 1980. The analytic hierarchy process. New York: John Wiley.

Saaty, T. L. 1997. That is not the analytic hierarchy process: what the AHP is and what it is not, Journal of Multi-Criteria Decision Analysis 6(6): 324-335.

Saaty, T. L. 2005. Theory and applications of the analytic network process: decision making with benefits, opportunities, costs, and risks. New York: RWS Publications.

Saaty, T. L. 2006. Rank from comparisons and from ratings in the analytic hierarchy/network processes, European Journal of Operational Research 168(2): 557-570.

http://dx.doi.org/10.1016/j.ejor.2004.04.032

Shiue, Y. C.; Lin, C. Y. 2012. Applying analytic network process to evaluate the optimal recycling strategy in upstream of solar energy industry, Energy and Buildings 54(November): 266-277. http://dx.doi.org/10.1016/j.enbuild.2012.07.032

Wei, X.; Andresso-O'Callaghan, B. 2008. Modelling EU FDI deflection between the new EU member states and Chinese provinces, Intereconomics May/June: 163-175. 
Wijnmalen, D. J. D. 2007. Analysis of benefits, opportunities, costs, and risks (BOCR) with the AHP-ANP: a critical validation, Mathematical and Computer Modelling 46: 892-905. http://dx.doi.org/10.1016/j.mcm.2007.03.020

Wind, Y.; Saaty, T. L. 1980. Marketing application of the analytic hierarchy process, Management science 7(26): 641-660.

Zavadskas, E. K.; Turskis, Z.; Kildiene, S. 2014. State of art surveys of overview on MCDM/ MADM, Technological and Economic Development of Economy 20(1): 165-179. http://dx.doi.org/10.3846/20294913.2014.892037

Zhang, K. H. 2014. How does foreign direct investment affect industrial competitiveness? Evidence from China, China Economic Review 30(September): 530-539.

http://dx.doi.org/10.1016/j.chieco.2013.08.003

Agné ŠIMELYTE். Holds a PhD in social sciences, works as an associate professor at the Department of Economics and Management of Enterprises of Vilnius Gediminas Technical University. She is the author and co-author of more than 20 scientific articles publicised in scientific journals and conference proceedings. Her research interests include foreign direct investment, FDI policy, MCDM.

Kęstutis PELECKIS. Doctor of social sciences (economics), works as a professor at the Department of Economics and Management of Enterprises of Vilnius Gediminas Technical University. He is the author and co-author of more than 100 publications. Research interests include the increase in the efficiency of business meetings and negotiations.

Renata KORSAKIENĖ. PhD, works as an associate professor at the Department of Economics and Management of Enterprises of Vilnius Gediminas Technical University. Her research interests involve strategic management, innovation management and change management of organisations. 